\title{
Thymus zygis and Thymus pulegioides as a source of phenolic compounds
}

\author{
Olívia R. Pereira ${ }^{1,2}, \underline{\text { Andrea F. Afonso }}{ }^{1,3}$, Vasco Domingues $^{2}$, Susana M. Cardoso ${ }^{2}$
}

${ }^{1}$ Department of Diagnostic and Therapeutic Technologies, School of Health Sciences, Polytechnic Institute of Bragança, Bragança, Portugal; ${ }^{2}$ CERNAS, School of Agriculture, Polytechnic Institute of Coimbra, Bencanta, Coimbra, Portugal, ${ }^{3}$ Public Health Laboratory of Bragança, Local Health Unit, Bragança, Portugal *scardoso@esac.pt

\section{INTRODUCTION}

Thymus are important genera of the Lamiaceae family that are well adapted to the climate of the Mediterranean region and are widespread in the arid parts of the Iberian Peninsula. Many species of Thymus are used for culinary confection and for medicinal applications [1]. Thymus plants are rich in phenolic compounds, particularly in phenolic acids and flavonoids [2]. Albeit that, the specific phenolic composition of T. zygis (Fig. 1) and T. pulegioides

(Fig. 2) remains unknown up to the present.

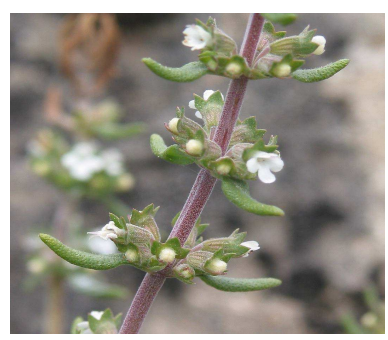

Figure 1. T. zygis

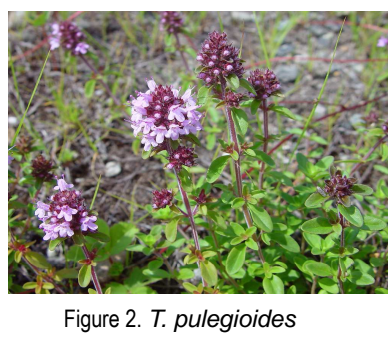

Figure 2. T. pulegioides
AIM: Determination of the phenolic composition of $T$. zygis and T. pulegioides.

\section{METHODS}

$\checkmark$ Extracts of the aerial parts of $T$. zygis and T. pulegioides species were prepared by extraction with hot water [3];

$\checkmark$ Total phenolic contents were determined according to the adapted Folin-Ciocalteu method [4];

$\checkmark$ Identification of the phenolic compounds was performed by high performance liquid chromatography (HPLC-DAD).<smiles>O=C(/C=C/c1ccc(O)c(O)c1)OC(Cc1ccc(O)c(O)c1)C(=O)O</smiles><smiles></smiles>

Figure 3 - Chemical structure of the three most abundant phenolic compounds in T. zygis and T. pulegioides extracts

\section{CONCLUSIONS}

T. zygis and $T$. pulegioides share the major phenolic constituents, although these two species can be distinguished by specific phenolic constituents in their composition.

\section{REFERENCES}

[1] Zarzuelo, A. and Crespo, E. 2002, The medicinal and non-medicinal uses of Thyme. In: Stahl-Biskup, E. and Sáez, F., editors. Thyme, the genus Thymus, London: Taylor and Francis. [2] Pereira, O.R. and Cardoso, S.M. (2013) Cur Anal Chem 9:382-396.

[3] Ferreira, F.M. et al. (2012) Cyta-J Food 10:92-102.

[4] Guyot, S. et al. (1998) J Agric Food Chem 46:1698-1705.

\section{RESULTS}

Aqueous extracts of $T$. zygis and T. pulegioides were enriched in caffeic acid derivatives, in particular rosmarinic acid and 3'-O-(8"Z-caffeoyl)rosmarinic acid (Table 1, Figure 3). Both extracts also contained moderate amounts of the flavone luteolin-7-Oglucoside (Table 1, Figure 3). Besides the common compounds, $T$. zygis had high levels of the phenolic acid salvianolic acid $\mathrm{K}$ and the extract of $T$. pulegioides was enriched in eriodictyol-Ohexoside and derivatives (Table 1).

Table 1- HPLC data of eluting fractions in aqueous extracts of $T$. zygis and $T$. pulegioides.

\begin{tabular}{|c|c|c|c|c|}
\hline $\begin{array}{c}\text { RT } \\
(\min )\end{array}$ & $\lambda_{\max }(\mathrm{nm})$ & MW & Compound & $\begin{array}{c}\text { Total } \\
\text { phenolics } \\
(\mu \mathrm{g} G A E / m g)^{a}\end{array}$ \\
\hline \multicolumn{5}{|c|}{ T. zygis } \\
\hline 11.9 & 290,328 & 360 & Rosmarinic acid & \multirow{4}{*}{$319 \pm 44$} \\
\hline 12.6 & 289,328 & 358 & $\begin{array}{l}3^{\prime}-0-\left(8^{\prime \prime}-Z-\right. \\
\text { caffeoyl)rosmarinic acid }\end{array}$ & \\
\hline 10.1 & $254,267,345$ & 448 & Luteolin-7-O-glucoside & \\
\hline 11.4 & 288,322 & 556 & Salvianolic acid K & \\
\hline \multicolumn{5}{|c|}{ T. pulegioides } \\
\hline 11.7 & 290,328 & 360 & Rosmarinic acid & \multirow{4}{*}{$391 \pm 3$} \\
\hline 12.5 & 289,328 & 358 & $\begin{array}{l}3^{\prime}-0-\left(8^{\prime \prime}-Z-\right. \\
\text { caffeoyl)rosmarinic acid }\end{array}$ & \\
\hline 9.9 & $254,267,345$ & 448 & Luteolin-7-O-glucoside & \\
\hline- & 282 & 450 & $\begin{array}{l}\text { Eriodictyol- } O \text {-hexoside and } \\
\text { derivatives }\end{array}$ & \\
\hline
\end{tabular}

a Determined by Folin-Ciocalteau assay

\section{ACKNOWLEDGEMENTS}

The authors acknowledge the financial support provided by the Financial support of FCT to CERNAS (PEst-OE/AGR/UI0681/2014). 